\section{Commercialization of British radio given an amber light}

London

UP to three national commercial radio networks and hundreds of community radio stations will emerge from the UK government's tacit approval dramatically to change the rules that constrain the number of UK radio stations.

The new guidelines, published in the form of a green paper (consultation document) last week entitled Radio: Choices and Opportunities (Cmnd 92, HMSO, f5.00), will end the monopoly of local commercial stations. Most of these stations enjoy sole commercial broadcasting rights in their areas and may now be challenged by community radio and national networks.

New broadcasting legislation will need to be introduced in the next session of parliament to allow the change. The British Broadcasting Corporation (BBC) will lose two of its seven frequencies. It will be given one in return in 1990 when more frequencies become available. International agreements will provide additional VHF/FM frequencies for broadcasting between the end of the decade and 1995. The government says these will provide "scope for new national and local services".

The national commercial radio service could fuel controversy. The advertising revenue on which the local stations depend could be threatened.

But the national network may have a higher proportion of speech to music and should be more of a challenger to the BBC's news channel, Radio 4, than the local commercial stations. That at least is the idea of the Independent Broadcasting Authority (IBA) currently the watchdog

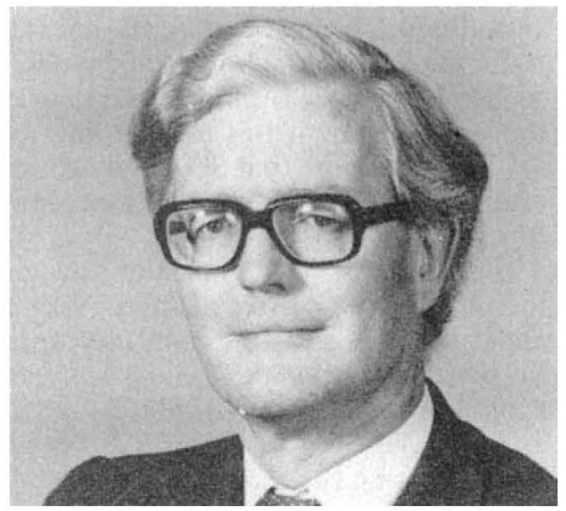

Douglas Hurd - planning a radio revolution

of the commercial radio stations.

The government does not want to restrict any commercial venture and is unlikely to impose a formula like that suggested by the IBA. At the community level there is expected to be an explosion.

Mr. Douglas Hurd, the Home Secretary says that "The values and traditions established by our history of high-quality public service broadcasting should not be lost, there can soon be a more varied pattern of radio services and more choice for the listener".
Bill Johnstone

\section{US Congress debating \\ Washington}

Speculation that Pakistan has "crossed the nuclear weapons threshold" put a crimp in last week's congressional hearings about a $\$ 4,020$ million US aid package to Pakistan. The Reagan administration wants the six-year package, an increase of $\mathbf{\$ 8 0 0}$ million over the last allotment, for economic and military support of Pakistan in the face of the continued Soviet presence in Afghanistan. But Congress is expected to ask some tough questions about Pakistan's nuclear capability.

Since 1985, US aid has been contingent on the US president verifying to Congress each October that Pakistan does not have a nuclear device. A report released this week by the Carnegie Endowment for International Peace indicates that Pakistan either "possesses all of the components needed" to manufacture an atom bomb or else "remains just short of this goal" because of a lack of enriched uranium.

The report, written by Leonard Spector, recounts the history of Pakistani attempts to acquire nuclear weapons technology.

\section{aid for Pakistan}

Spector cites as one example the purchase of a plutonium reprocessing facility from France in the mid-1970s which would have permitted Pakistan to accumulate nuclear weapons material. The United States cut off aid to Pakistan in 1976 over precisely this issue. Deliveries for the facility were ultimately suspended and US aid reinstated in 1977. Aid was cut off again in 1979, when it had been found that Pakistan had been acquiring technology for uranium enrichment, and was restored only in 1981, after Soviet forces appeared in Afghanis$\tan$

The administration recently warned Pakistan that US aid may be cut off once again if Pakistan is found to possess even the makings of a bomb. In a speech in Islamabad on 16 February, US Ambassador Deane Hinton warned that under such conditions, it would be "open to question" whether the president could make the necessary certification. Pakistan continues to deny that it is developing nuclear weapons. Congress will decide on aid in the next few months.

\section{Government and students make peace in Spain}

\section{Barcelona}

THE Spanish minister of education and science, José Maria Maravall, has signed agreements with most of the student organizations that led demonstrations against the Spanish educational system during the past two months. Some radical student organizations have decided to continue the movement, but most students have returned to their classrooms. The agreement is based on a proposal by the minister that includes a gratuity for secondary school students under 16 and for university students from families under a certain income, a substantial increase in the number of fellowships, reforms in the secondary schools and a revision of the entry requirements for universities.

Both sides claim victory. The students say they have forced the minister to negotiate and to accept some of their points. $\mathrm{He}$ in turn has declared that the agree-

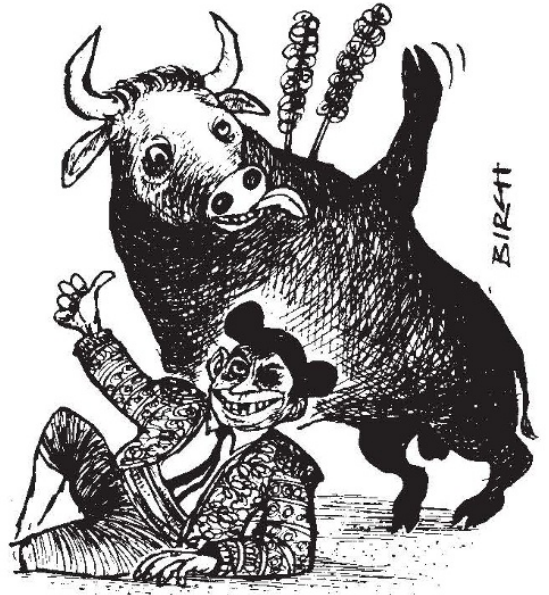

ment does not mean a departure from his policy but only an acceleration of the reforms already under way.

Most students have returned to class but the unrest has spread to previously unaffected universities. At the Autonomous University of Barcelona police entered the campus to expel students occupying the main administrative building, and the university was closed for two days. This was the first such incident in Spain for more than ten years.

It is clear that the agreement between the minister of education and students will be costly. It is calculated at about 40,000 million pesetas per year ( $£ 200$ million), almost twice the budget of the CSIC (the Spanish research council). It is not clear where the money will come from and some people fear that proposed increases in university or research funds or salaries may be frozen as a consequence.

Pedro Puidoménech 